\title{
Gender differences in perception of the university education quality as applied to entrepreneurial intention
}

\section{Gentjan Çera}

Department of Enterprise Economics,

Tomas Bata University in Zlin

Czech Republic

cera@utb.cz.

\section{Martin Cepel}

Faculty of Economics and Business,

Paneuropean University Bratislava

Slovakia

cepel@benzinol.com

\section{Sandra Zakutna}

Philosophical Faculty,

Prešov University in Prešov

Slovakia

sandra.zakutna@unipo.sk

\section{Zoltan Rozsa}

Department of Management,

School of Economics and Management in Public Administration in

Bratislava, Slovakia

roltan.rozsa@vsemvs.sk

Abstract. The aim of this paper is to examine how university students perceive the selected attributes of university education quality in the context of their possible entrepreneurial activities and to explore the differences between genders in this regard. A total of 977 students from Czech and Slovak universities were surveyed. The Z-test for two population proportions was employed to test the hypotheses. The majority of university students positively perceived the quality of university education in general as well as the quality of education at their faculty. Approximately two thirds of the students in both countries agreed that the acquired knowledge may help them in their future entrepreneurship activities. Czech students perceived the quality of education more positively compared to their Slovak counterparts, despite the fact that they had lower entrepreneurial intention. This research shows there are differences in male and female students' views. In both countries, female students perceived the quality of education more positively, whereas male students declared a statistically higher interest in

Received:

February, 2018

1st Revision:

May, 2018

Accepted:

July, 2018

DOI:

$10.14254 / 2071$ $8330.2018 / 11-3 / 13$ 
entrepreneurial activity as compared to female students. The results of this paper could guide universities and policymakers in designing study programs in entrepreneurship responding better to gender needs so that to increase entrepreneurial participation.

Keywords: students, quality of education, entrepreneurial intention, gender.

JEL Classification: M13, D83

\section{INTRODUCTION}

Investment in the provision of quality education is an important factor for economic growth in any country. The European Union countries need innovative and creative entrepreneurs as well as flexible workforce with the necessary skills and key competencies. In its strategy, the European Commission (EC) calls on the Member States to provide practical entrepreneurial skills before completing compulsory school attendance, while stressing the importance of practical education and training (European Commission, 2012). In the context of the EC document, the explicit need for efforts to develop crosscutting skills such as entrepreneurship was explicitly emphasized. These skills include, inter alia, the ability to critically think, take initiative, actively solve problems and work together.

Implementation of these processes can be much more complicated in individual countries. Due to the heterogeneity of education systems, different levels of the transformation processes, the current economic situation, globalization as well as the political development of the countries, differences in innovativeness and in the flexibility level of learning processes in both national and international contexts can be observed (Mueller \& Thomas, 2001).

Nowadays, the gender gap is another issue of the growing interest. It has been observed that in Europe, females are only half as likely to engage in entrepreneurial activities when compared with males (Herrington \& Penny, 2017). According to (Minniti \& Naudé, 2010) research, females do significantly less often start a firm than men. In order to ensure gender equality, scholars are trying to establish the factors influencing these differences in gender disposition towards engaging in entrepreneurship.

Hence, these empirical observations inform the motivation for conducting the proposed study. Firstly, the research is focused on the process of higher education in the context of preparation for future entrepreneurial activities, and then - on finding differences in gender perception among the university students. Since in the recent years migration of Slovak students to Czech Republic has been quite noticeable, differences in perception of the higher education quality among Czech and Slovak students are also investigated here.

\section{LITERATURE REVIEW}

Scholars have been focused on analyzing and evaluating the impact of various social and economic factors on entrepreneurship using undergraduate students as a research unit. Both qualitative and quantitative research settings were used. The majority of studies have drawn their research setting based on the theory of planned behavior, formulated by Ajzen (1991), which supposes that there are three antecedents that drive individual behavioral intentions: attitudes towards the behavior, subjective norms and perceived behavior control. Moreover, two other theoretical perspectives are considered of great importance in this regard: buman capital theory proposed by Becker in 1975 (Becker, 1994), which suggests that an entrepreneurship education may lead to the promotion of a student's attitudes and intentions, including business start-ups; and entrepreneurial self-efficacy (Chen, Greene, \& Crick, 1998), which proposes a relation 
among behavior, cognition, and environment, and it refers to a belief in the ability of a person to do several roles and tasks dealing with entrepreneurship.

The importance of education for decision-making on the entrepreneurship start-up as well as on the development of future entrepreneurial activities is presented by numerous scholars ( Belas et al., 2017a; Belas et al., 2017b; Hamida, Trabelsi, \& Boulila, 2017; Jansen, van de Zande, Brinkkemper, Stam, \& Varma, 2015; Liñán \& Fayolle, 2015; Mondragón-Vélez, 2009; Marinoiu et al., 2017). In this context, Sánchez (2011) states that education is an important stimulus for starting a business as it promotes a sense of independence and self-confidence, educates people to have good knowledge of alternative job opportunities, and education expands the individual's perceptions. The most important factor is that education provides the knowledge that individuals can use to develop new business opportunities (Popov et al., 2016; Skačkauskienè et al., 2017). This leads to the relation between entrepreneurship education and entrepreneurial intention. Entrepreneurship education is defined as any study program or process of education for entrepreneurial attitudes and skills, whereas entrepreneurial intention consists of somebody's desire to run a business (Bae, Qian, Miao, \& Fiet, 2014; Fayolle \& Liñán, 2014).

Nowadays, to stay competitive, universities are trying to become more entrepreneurial, generate new sources of income, and act in accordance to government's policy guidelines. Undoubtedly, their students are the most powerful resource they have to foster entrepreneurship (Lazányi, 2014). Entrepreneurship education provides a variety of training programs for bachelors, masters and postgraduates (Nieuwenhuizen, Groenewald, Davids, Janse van Rensburg, \& Schachtebeck 2016). Their study programs offer an opportunity for the establishment of new firms. Through entrepreneurship education, university students gain skills concerning organizational issues, such as time management, leadership and interpersonal skills (Stamboulis \& Barlas, 2014). The entrepreneurship intentions of students are influenced by demographic factors (Father's occupation, Gender, Experience and Level of education) (Mohammad Ahmar Uddin, Shariq Mohammad, \& Samir Hammami, 2016). Social values also have an impact on the entrepreneurship intentions (Kalitanyi \& Visser, 2016). Harris and Gibson (2008) report that the role of the university is important for fostering students start-up activities. University atmosphere and learning progress impact career motivation, attitudes and perceived behavior control(García-Rodríguez, Gil-Soto, Ruiz-Rosa, \& Gutiérrez-Taño, 2017), and being a student enrolled in university may enhance entrepreneurial knowledge (Hahn, Minola, Van Gils, \& Huybrechts, 2017, Naushad, 2018). According to Fayolle and Gailly's (2015), a study program on entrepreneurship has more positive effect when students' previous entrepreneurial exposure has been weak or nonexistent. Farhangmehr, Gonçalves and Sarmento (2016) emphasize the importance of technical knowledge, personality traits for starting a business, which are reflected in the innovative capabilities and analytical characteristics of future entrepreneurs. Even though the entrepreneurship education offered at universities is increased, there is a continuing debate whether and under which circumstances the study programs contribute to students' entrepreneurial learning (Bergmann, Hundt, \& Sternberg, 2016; Hahn et al., 2017). Nevertheless, so far, there is no consolidated theory on how to inspire students to become entrepreneurs (Jansen et al., 2015; Bogdanović et al., 2018).

Many studies have confirmed that entrepreneurs with higher education have significantly better business prospects (Lafuente \& Vaillant, 2013; Mondragón-Vélez, 2009) and this type of education is associated with higher sales volume, higher profitability and sustainability of the company to a great extent (Rauch \& Rijsdijk, 2013). Urbano, Aparicio, Guerrero, Noguera and Torrent-Sellens (2017) tried to estimate the probability of becoming a student employer entrepreneur, and found that gender has a statistical significance in this regard. Additionally, Johansen's (2013) results show a positive correlation between participation in the European entrepreneurship program, which promotes youth to establish a new enterprise, and start-up activity. Nevertheless, these analyses also show a gender gap: this program has less effect on female start-up activity as compared to male. 
An interesting fact in many researchers focused on the tendency for entrepreneurship of university students is the structuring of their results by gender. This is due to changes in the current position of women in society and other factors. Females now have much greater opportunities to pursue their professional career than they did in the past. Also, for many females, entrepreneurship was the only way to be employed and working. According to Kirkwood, Dwyer and Gray (2014), differences in gender in entrepreneurial intentions, such as differences in male and female thinking about new enterprise start-ups, might be addressed by the education system (Díaz-García \& Jiménez-Moreno, 2010; Johansen, 2013).

Prior research has found that males, compared to females, have higher entrepreneurial self-efficacy (Mueller \& Dato-On, 2008; Wilson, Kickul, \& Marlino, 2007), greater intentions to become an entrepreneur (Liñán \& Fayolle, 2015), and stronger potential for success as an entrepreneur (Mueller \& Thomas, 2001). Interesting findings are found by Wilson et al. (2007), who examined the degree of business autonomy in males and females. Business is still perceived as a "male" area, but their research has shown that females' entrepreneurial higher education reduces significant gender gaps and encourages their entrepreneurial intentions. Thus, entrepreneurial education can be seen as a significant factor in increasing the chances of females to be successful in business (Lazányi, 2014b). In addition, Haus, Steinmetz, Isidor and Kabst (2013) conclude that females transform their intentions into action to a much lesser extent than do males. Also, females felt more intensive support of their surroundings for entrepreneurship than males (Kljucnikov, Belas, Kozubikova, \& Pasekova, 2016). Concerning this, females tend to perceive different barriers to entrepreneurship (Shinnar, Giacomin, \& Janssen, 2012), and they may be less expected to act on their entrepreneurial intentions (Shinnar, Hsu, Powell, \& Zhou, 2018; Westhead \& Solesvik, 2016).

The role of gender in forming attitudes of university students towards entrepreneurship is found as important (Entrialgo \& Iglesias, 2016; Haus et al., 2013; Sánchez-Escobedo, Díaz-Casero, HernándezMogollón, \& Postigo-Jiménez, 2011). Dawson and Henley's (2015) results suggest strong associations between entrepreneurial intention, gender, and attitude to risk. Bergmann, Geissler, Hundt and Grave (2018) found university entrepreneurship measures to have a positive effect on students' climate perceptions, which also depend on students' background and gender, whereas as for the desire to start a business, the differences are not striking. What is interesting, however, is the difference between males and females regarding the firm commitment of students to start self-employment. Sánchez-Escobedo et al. (2011) found that $31 \%$ of males and $22 \%$ of females from their sample size declared a firm commitment. Similar results were also provided by Harris and Gibson (2008) research into US student business plans. According to them, entrepreneurial intentions were present in most students regardless of gender, but a higher tendency towards entrepreneurship was evident in the male population. Dabic et al., (2012) also found that female students were less willing to start their own business than male students. This finding is explained by the fact that females are less self-confident and more aware of stress of entrepreneurial activities than males. Similar results have also been obtained by Packham et al., (2010) and Goel et al., (2015).

Harris and Gibson (2008) justify accepting a higher rate of business risk in relation to the innovation rate found predominantly in males as well as family business experience. The solution to this situation is offered by Setiawan (2014), which calls for the use of various psychological activities alongside business education programs. The significance of these psychological programs is that students learn to manage stress and manage unfavourable situations associated with unexpected and challenging changes and challenges that are common in the business world. These programs are likely to encourage greater business interest in women by eliminating business-related stress. Kozubíková et al., (2015, 2016, 2017) found that state and public perception shows to be much more important in the perception of financial risk for females than males.

These studies are very inspirational because they point to the differences between countries as well as to find who causes these differences (such as gender, age, social etc.) and support subsequent research in 
the field. Previous studies were also an inspiration for developing our research, examining the differences in the quality of study regarding the potential start-up activities of university students in the Czech and Slovak Republics.

\section{AIM, METHODOLOGY AND DATA}

The aim of the paper is to examine how university students evaluate selected attributes of the quality of university education in the Czech Republic and Slovakia in the context of their possible entrepreneurial activities and to find differences between male and female students.

The quality of higher education was measuredusing the following statements: I consider the bigher education in my country as quality; I consider the education system at my faculty (university) to be a good one; The knowledge I get at my faculty (university) helps me in doing business; The lessons learned by students in my country will belp them start a business. The entrepreneurial intention of university students was measured by a single statement: I have a strong interest in doing business. Students were asked to read them and to answer by selecting one of the five-point Likert scale: [1] Strongly agree;[2] Agree;[3] Neither Agree Nor Disagree;[4] Disagree;[5] Strongly disagree.

The discussion in the literature on this subject, mentioned in previews section, leads to five scientific hypotheses, which were formulated as below:

H1: More than $50 \%$ of students rate higher education in general as good. There are no statistically significant differences in the positive answers of students in the Czech Republic and Slovakia. There are no statistically significant differences in the positive responses of students according to their gender in the Czech Republic and Slovakia.

H2: More than $50 \%$ of students evaluate higher education at a faculty where they study as good. There are no statistically significant differences in the positive answers of students in the Czech Republic and Slovakia. There are no statistically significant differences in the positive responses of students according to their gender in the Czech Republic and Slovakia.

H3: More than $50 \%$ of students think that the knowledge they have gained at the faculty where they study helps them in business. There are no statistically significant differences in the positive answers of students in the Czech Republic and Slovakia. There are no statistically significant differences in the positive responses of students according to their gender in the Czech Republic and Slovakia.

H4: More than $50 \%$ of students think that the knowledge they have gained in a given country will help them start a business. There are no statistically significant differences in the positive answers of students in the Czech Republic and Slovakia. There are no statistically significant differences in the positive responses of students according to their gender in the Czech Republic and Slovakia.

H5: Less than 50\% of students in the Czech Republic and Slovakia have a potential interest in doing business in the future. There are no statistically significant differences in the assessment of the tendency for entrepreneurship of university students in the Czech Republic and Slovakia. There are no statistically significant differences in the positive responses of students according to their gender in the Czech Republic and Slovakia.

Hypotheses were tested by performing $\mathrm{Z}$ test for two population proportions to $5 \%$ significance level (Social Science Statistics, n.d.).

In connection with the stated research objective, a questionnaire was designed and delivered among university students in the Czech Republic and Slovakia. Students have filled it in while they were in the class supervised by a lecturer. Older students (in the third year of study and older) were part of our sample because it was suppose that they think on their future career more than the younger ones.409 students from 14 Czech universities and 568 students from 8 Slovakian universities were surveyed. The Czech students were from the following universities: Technical University of Liberec, Newton College in Brno, University of 
Applied Business, University of Economics Prague, Masaryk University in Brno, Sting Academy in Brno, College of Entrepreneurship and Law in Prague, Palacký University Olomouc and the Mendel University Brno. Students from Slovakia were studying at the following universities: University of Economics in Bratislava, Alexandr Dubček University in Trenčín, University of Žilina, University of Prešov, Matej Bela University in Banská Bystrica, Technical University of Zvolen, Technical University of Košice, PanEuropean University in Bratislava. All together were 977 students, where $38 \%$ of them were males and $62 \%$ females.

\section{EMPIRICAL RESULTS AND DISCUSSION}

Table 1 summarizes the responses of university students regarding the statement $I$ evaluate the higher education in my country as being of high quality. In the Czech Republic, up to $68 \%(=[5+91+13+171] / 409)$ of students evaluated university education in general as good, whereas in the Slovak Republic, only $52 \%$ of the quality of higher education was positively evaluated. Statistically significant differences were found in the positive answers between the Czech and Slovak students, $z=5.284, p<0.001$. In addition, it was found statistically significant differences in positive responses of students by gender. In both countries, females rated more positively the quality of higher education than males. The highest degree of being "agree" with the two statements (Strongly agree and Agree) was shown by female students in the Czech Republic, of which up to $73 \%(=[13+171] / 253)$ evaluated higher education as quality. Thus, first hypothesis (H1) was fully supported.

Table 1

Results of "I evaluate the higher education in my country as being of high quality"

\begin{tabular}{|c|c|c|c|c|c|c|c|c|c|c|}
\hline & \multirow{2}{*}{\multicolumn{2}{|c|}{$\begin{array}{c}\text { Czech } \\
(\mathrm{n}=409)\end{array}$}} & \multirow{2}{*}{\multicolumn{2}{|c|}{$\begin{array}{c}\text { Slovak } \\
(\mathrm{n}=568)\end{array}$}} & \multicolumn{6}{|c|}{$\mathrm{Z}$ test for 2 population proportions } \\
\hline & & & & & \multicolumn{2}{|c|}{ Czech \& Slovak } & \multicolumn{2}{|c|}{ Czech M-F } & \multicolumn{2}{|c|}{ Slovak M-F } \\
\hline & M & $\mathrm{F}$ & M & $\mathrm{F}$ & Value & $\mathrm{p}$-value & Value & $\mathrm{p}$-value & Value & $\mathrm{p}$-value \\
\hline Strongly agree $(S A)$ & 5 & 13 & 12 & 14 & & & & & & \\
\hline $\operatorname{Agree}(A)$ & 91 & 171 & 84 & 183 & & & & & & \\
\hline$(S A+A) /$ Total & $62 \%$ & $73 \%$ & $44 \%$ & $56 \%$ & & & -2.365 & 0.018 & -2.667 & 0.008 \\
\hline$(S A+A) / n$ & & & & & 5.284 & 0.000 & & & & \\
\hline $\begin{array}{l}\text { Neither Agree } \\
\text { Nor Disagree }\end{array}$ & 23 & 24 & 40 & 34 & & & & & & \\
\hline Disagree & 33 & 42 & 73 & 98 & & & & & & \\
\hline Strongly disagree & 4 & 3 & 7 & 23 & & & & & & \\
\hline Total & 156 & 253 & 216 & 352 & & & & & & \\
\hline
\end{tabular}

Source: Authors' results.

Similar to Table 1, Table 2 shows the results of university students' answers regarding the statement $I$ evaluate the system of education at my faculty (university) as a quality one. In the Czech Republic, up to $71 \%$ of students have positively evaluated university education at the faculty where they study, whereas this percentage in the Slovak Republic was $67 \%$. No statistically significant differences were found in positive responses between the Czech and Slovak students, $z=1.387, p=0.165$. However, statistically significant differences were found in the positive responses of students by gender in the Czech Republic, $z=-2.154, p=0.032$. Female students in the Czech Republic perceived the education system at their faculty as being of high quality. In contrast to the Czech case, it was not detected any statistically significant differences in Slovak 
students positive responses by gender, $z=-1.307, p=0.190$. Considering three test results, second hypothesis (H2) was partially supported.

Table 2

Results of "I evaluate the system of education at my faculty (university) as a quality one"

\begin{tabular}{|c|c|c|c|c|c|c|c|c|c|c|}
\hline & \multirow{2}{*}{\multicolumn{2}{|c|}{$\begin{array}{c}\text { Czech } \\
(n=409)\end{array}$}} & \multirow{2}{*}{\multicolumn{2}{|c|}{$\begin{array}{c}\text { Slovak } \\
(n=568)\end{array}$}} & \multicolumn{6}{|c|}{$\mathrm{Z}$ test for 2 population proportions } \\
\hline & & & & & \multicolumn{2}{|c|}{ Czech \& Slovak } & \multicolumn{2}{|c|}{ Czech M-F } & \multicolumn{2}{|c|}{ Slovak M-F } \\
\hline & $\mathrm{M}$ & $\mathrm{F}$ & $\mathrm{M}$ & F & Value & $\mathrm{p}$-value & Value & p-value & Value & p-value \\
\hline Strongly agree $(S A)$ & 17 & 24 & 28 & 28 & & & & & & \\
\hline $\operatorname{Agree}(A)$ & 84 & 165 & 109 & 214 & & & & & & \\
\hline$(S A+A) /$ Total & $65 \%$ & $75 \%$ & $63 \%$ & $69 \%$ & & & -2.154 & 0.032 & -1.307 & 0.190 \\
\hline$(S A+A) / n$ & & & & & 1.387 & 0.165 & & & & \\
\hline $\begin{array}{l}\text { Neither Agree } \\
\text { Nor Disagree }\end{array}$ & 25 & 25 & 25 & & & & & & & \\
\hline Disagree & 27 & 36 & 48 & 74 & & & & & & \\
\hline Strongly disagree & 3 & 3 & 6 & 8 & & & & & & \\
\hline Total & 156 & 253 & 216 & 352 & & & & & & \\
\hline
\end{tabular}

Source: Authors' results.

Table 3 summarizes the results concerning statement The knowledge I am obtaining at my faculty (university) would help me in my entrepreneurship. Based on the results in both countries, more than $50 \%$ of students thought that the knowledge they had gained at the faculty where they were studying would help them in business. No statistically significant differences were found in the positive answers between the Czech and Slovak students, $z=1.262, p=0.208$. Also, there was not found any statistically significant differences in the students' responses according to their gender neither in the Czech Republic nor in Slovakia. Based on these results, it might be concluded that third hypothesis (H3) has been partially confirmed.

Results of "The knowledge I am obtaining at my faculty (university) would help me in my entrepreneurship"

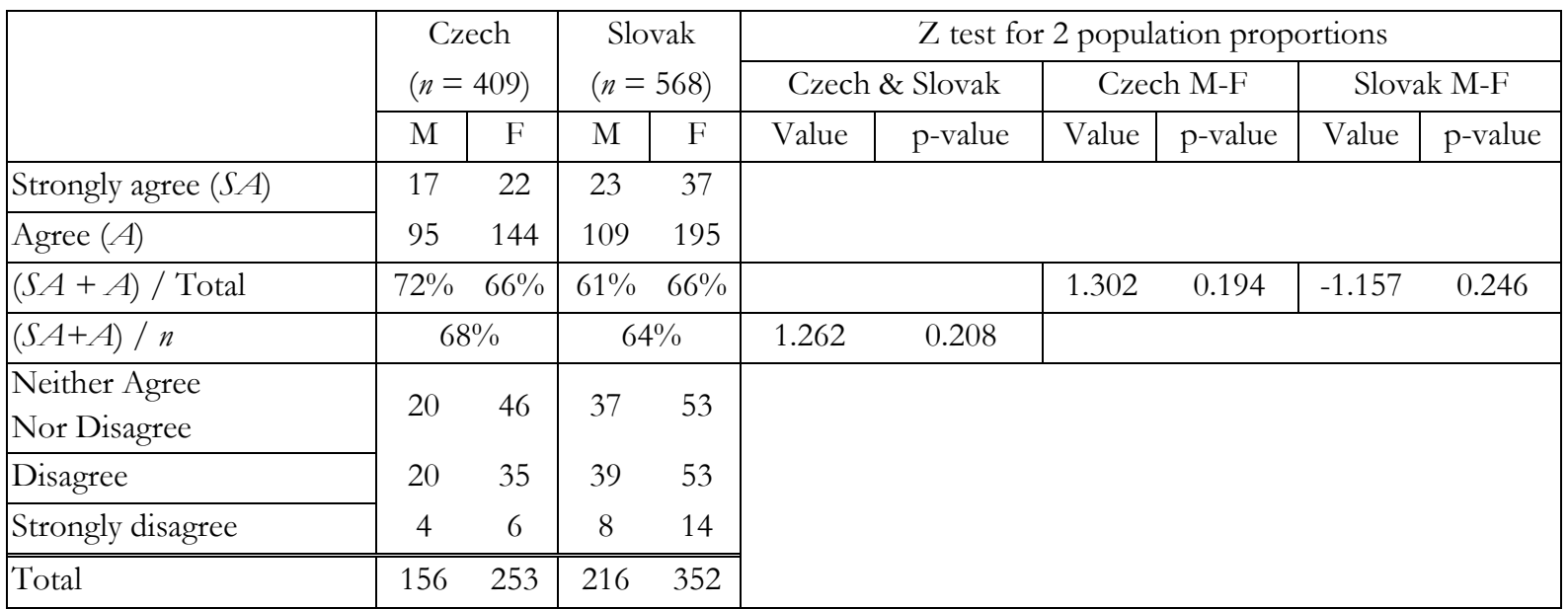

Source: Authors' results. 
The fourth hypothesis (H4) was partially confirmed. Table 4 shows the test results referring to the statement The knowledge students are obtaining in my country would belp them to start a business. More than 50\% of students in both countries said that the knowledge they gained in their country would help them to start a business. Concerning differences in gender, neither at Czech nor at Slovak students was not found any statistical differences. The values of the test confirmed that there are no statistically significant differences in the positive answers of among them regarding gender.

Table 4

Results of "The knowledge students are obtaining in my country would help them to start a business"

\begin{tabular}{|c|c|c|c|c|c|c|c|c|c|c|}
\hline & \multirow{2}{*}{\multicolumn{2}{|c|}{$\begin{array}{c}\text { Czech } \\
(\mathrm{n}=409)\end{array}$}} & \multirow{2}{*}{\multicolumn{2}{|c|}{$\begin{array}{c}\text { Slovak } \\
(n=568)\end{array}$}} & \multicolumn{6}{|c|}{$\mathrm{Z}$ test for 2 population proportions } \\
\hline & & & & & \multicolumn{2}{|c|}{ Czech \& Slovak } & \multicolumn{2}{|c|}{ Czech M-F } & \multicolumn{2}{|c|}{ Slovak M-F } \\
\hline & $\mathrm{M}$ & $\mathrm{F}$ & $\mathrm{M}$ & $\mathrm{F}$ & Value & $\mathrm{p}$-value & Value & $\mathrm{p}$-value & Value & $\mathrm{p}$-value \\
\hline Strongly agree $(S A)$ & 2 & 8 & 10 & 19 & & & & & & \\
\hline Agree $(A)$ & 87 & 132 & 103 & 177 & & & & & & \\
\hline$(S A+A) /$ Total & $57 \%$ & $55 \%$ & $52 \%$ & $56 \%$ & & & 0.339 & 0.728 & 0.782 & 0.435 \\
\hline$(S A+A) / n$ & & $\%$ & 5 & & 0.493 & 0.624 & & & & \\
\hline $\begin{array}{l}\text { Neither Agree } \\
\text { Nor Disagree }\end{array}$ & 44 & 67 & 49 & 56 & & & & & & \\
\hline Disagree & 22 & 42 & 48 & 92 & & & & & & \\
\hline Strongly disagree & 1 & 4 & 6 & 8 & & & & & & \\
\hline Total & 156 & 253 & 216 & 352 & & & & & & \\
\hline
\end{tabular}

Source: Authors' results.

The answers and statistical test results for the entrepreneurial intention of university students are shown in Table 5. According to the results, 49\% of the Czech students and 59\% the Slovak students confirmed a strong interest in entrepreneurship. The values of the test $(z=-2.917, p=0.004, z=6.099, p<0.001, z=$ 2.280, $p=0.023$ ) confirmed that there are statistically significant differences for entrepreneurial intention between the Czech and the Slovak students. Slovak students have statistically significantly higher entrepreneurial intention than Czech students. Same results are found even when males were compared to females in both countries. Moreover, it was found that male students expressed interest in doing business significantly more in both countries compared to females. Consequently, the fifth hypothesis (H5) has been partially confirmed.

Referring to the results, $49 \%$ of Czech university students have a strong interest in doing business, so they have strong entrepreneurial intention. These results are comparable to other sources. For instance, according to BusinessInfo.cz (2014), up to 50\% of undergraduate students are considering doing business in the future.

Concerning the gender gap debate, our results were consistent with previews scholars' findings, which concluded that business is still perceived as a male issue in the footprint (Dawson \& Henley, 2015; Johansen, 2013; Minniti \& Naudé, 2010). Furthermore, gaps are shown at the least in entrepreneurship education and entrepreneurial intention relation, supporting that females are less oriented towards entrepreneurship compared to males (Cañizares \& García, 2010; Goktan \& Gupta, 2015; Joensuu-Salo, Varamäki, \& Viljamaa, 2015; Maes, Leroy, \& Sels, 2014; Maresch, Harms, Kailer, \& Wimmer-Wurm, 2016; Perez-Quintana, Hormiga, Martori, \& Madariaga, 2017; Shirokova, Tsukanova, \& Morris, 2018). Similar results were found even in other European countries (i.e. see Dabic et al., 2012). Furthermore, regarding entrepreneurship 
education, Walter, Parboteeah and Walter (2013) were focused only at public universities in Germany, and found that males were more likely to score higher than females.

Table 5

Results of "I have substantial interest in entrepreneurship"

\begin{tabular}{|c|c|c|c|c|c|c|c|c|c|c|}
\hline & \multirow{2}{*}{\multicolumn{2}{|c|}{$\begin{array}{c}\text { Czech } \\
(n=409)\end{array}$}} & \multirow{2}{*}{\multicolumn{2}{|c|}{$\begin{array}{c}\text { Slovak } \\
(n=568)\end{array}$}} & \multicolumn{6}{|c|}{$\mathrm{Z}$ test for 2 population proportions } \\
\hline & & & & & \multicolumn{2}{|c|}{ Czech \& Slovak } & \multicolumn{2}{|c|}{ Czech M-F } & \multicolumn{2}{|c|}{ Slovak M-F } \\
\hline & $\mathrm{M}$ & F & $\mathrm{M}$ & $\mathrm{F}$ & Value & p-value & Value & p-value & Value & $\mathrm{p}$-value \\
\hline Strongly agree $(S A)$ & 38 & 26 & 48 & 41 & & & & & & \\
\hline Agree $(A)$ & 69 & 69 & 92 & 153 & & & & & & \\
\hline$(S A+A) /$ Total & $69 \%$ & $38 \%$ & $65 \%$ & $55 \%$ & & & 6.099 & 0.000 & 2.280 & 0.023 \\
\hline$(S A+A) / n$ & & & & & -2.917 & 0.004 & & & & \\
\hline $\begin{array}{l}\text { Neither Agree } \\
\text { Nor Disagree }\end{array}$ & 24 & 58 & 45 & & & & & & & \\
\hline Disagree & 21 & 83 & 21 & 72 & & & & & & \\
\hline Strongly disagree & 4 & 17 & 10 & 12 & & & & & & \\
\hline Total & 156 & 253 & 216 & 352 & & & & & & \\
\hline
\end{tabular}

Source: Authors' results.

Although the decision to start a business is determined by other factors, university education plays an important role in this process. This is consistent with the findings of Zollo et al., (2017) and Shirokova et al., (2016), which show that the university environment has a significant impact on students in their business attitude and intentions (Bergmann et al., 2018, 2016; Hahn et al., 2017; Trivedi, 2016). In addition, Walter et al. (2013) point out that during the course of higher education, the four factors of the organization of study that play a key role in the future business of students are: entrepreneurial education, support programs for entrepreneurship, interconnection with industry, and research orientation. In this context, it is important to improve the quality of education, particularly through the development of entrepreneurial skills and competencies as the main factors of motivation for start-ups activities (Doğan, 2015; Farhangmehr et al., 2016; Shirokova, Osiyevskyy, Morris, \& Bogatyreva, 2017). However, entrepreneurship education generally has a greater effect on business and social sciences students (Marques et al., 2018).

Audretsch (2014) points to the necessary transformation of the role of the university in relation to university education. Although universities are sufficiently entrepreneurial, today they are no longer sufficient because they need to respond to their roles in the business community and broaden their intention to improve their entrepreneurial capital and entrepreneurial behavior. Van Looy et al. (2011), conducted a research within 105 European universities, advocate the need for universities to enter the business environment through their scientific activities that enable them to succeed in their business. Filippetti and Savona (2017) emphasize that universities are directly linked to the manufacturing sphere and other organizations in order to cope with the lack of finance and get key knowledge (Jansen et al., 2015). Consequentially, universities should apply a strategy in order to bring together local partners in support of young entrepreneurs (Bezerra, Borges, \& Andreassi, 2017). Nabi et al., (2017) highlight the need for further research on the impact of entrepreneurial education at universities, focusing on the use of innovative indicators with an emphasis on emotion and mind setting or the transition from intention to action.

All things considered, it is clear that high-quality education in entrepreneurship requires an ongoing support for entrepreneurial and innovation capabilities, which should be part of study disciplines. Although the effect of introducing innovative forms of teaching is more meaningful in the long run. Previous studies 
suggest that to support entrepreneurship education it is essential to build various university business centers, that are supportive, specialized teaching facilities of public universities (or research and development centers), for the preparation of experts for business practice and employment in regions. On the other hand, in the context of policy implication, since government and industrial or financial support directly influence academic entrepreneurial intention (Feola et al., 2017), there is still room to improve and to foster entrepreneurship spirit in the universities. The quality of learning processes oriented at supporting entrepreneurial activities can also be improved by involving experts from other sectors in educational activities, introducing different innovative and alternative forms of education as well as teaching methods in the study fields, constantly developing key competencies, especially concerning language and information communication technology skills (Arokiasamy, 2017; Pudlo \& Gavurova, 2012, 2013). These solutions must also be implemented in different regional and national education policies and ensure their link to the funding system and other important processes for their functioning (Feola et al., 2017).

\section{CONCLUSION}

The aim of the article was to examine how the Czech and Slovakia university students perceive selected attributes of the quality of higher education in the context of their possible entrepreneurial activities and to further explore the differences between different gender groups of students. Based on the results of this study, the majority of university students have shown that they perceive the quality of higher education in general and also the quality of study at their home faculty as a good one. About two-thirds of students in both countries expressed the view that university education might help them in their future business activities.

The results of our research includes an interesting finding. Higher education students in the Czech Republic perceived more positively the quality of higher education than Slovak university students, but, on the other hand, they have statistically significant lower propensity for entrepreneurship. In this study, differences in students' views by gender were found. In both countries, females rated more positively the quality of higher education compared to men. At the same time, male students showed more interest in doing business compared to women in both countries.

This research has some limitations because it was implemented on a limited but representative sample of respondents. The results of our research represent a valuable platform for subsequent research as well as for developing concepts within the national and regional policies to foster entrepreneurship in both countries.

\section{ACKNOWLEDGEMENT}

The authors are thankful to the Internal Grant Agency of FaME TBU No. IGA/FaME/2017/010: Financial Constraints on Economic Activities, for financial support to carry out this research.

\section{REFERENCES}

Ajzen, I. (1991). The theory of planned behavior. Organizational Behavior and Human Decision Processes, 50(2), $179-211$. https://doi.org/10.1016/0749-5978(91)90020-T

Arokiasamy, A. (2017). A systematic review approach of mobile technology adoption in higher education. Economics, Management and Sustainability, 2(2), 48-55. https://doi.org/10.14254/jems.2017.2-2.5

Audretsch, D. B. (2014). From the entrepreneurial university to the university for the entrepreneurial society. The Journal of Technology Transfer, 39(3), 313-321. https://doi.org/10.1007/s10961-012-9288-1

Bae, T. J., Qian, S., Miao, C., \& Fiet, J. O. (2014). The Relationship Between Entrepreneurship Education and Entrepreneurial Intentions: A Meta-Analytic Review. Entrepreneurship Theory and Practice, 38(2), 217-254. 
https://doi.org/10.1111/etap.12095

Becker, G. S. (1994). Human capital revisited. In Human Capital: A Theoretical and Empirical Analysis with Special Reference to Education (3rd ed., pp. 15-28). The university of Chicago press.

Zvarikova, K., \& Kacerauskas, T. (2017). Social and economic factors affecting the entrepreneurial intention of university students. Transformations in Business \& Economics, 16(3), 220-239.

Belás, J, Dvorský, J., Tyll, L., Zvaríková, K. (2017b). Entrepreneurship of university students: important factors and the propensity for entrepreneurship. Administratie si Management Public, (28), 6-25.

Bergmann, H., Geissler, M., Hundt, C., \& Grave, B. (2018). The climate for entrepreneurship at higher education institutions. Research Policy, 47(4), 700-716. https://doi.org/10.1016/J.RESPOL.2018.01.018

Bergmann, H., Hundt, C., \& Sternberg, R. (2016). What makes student entrepreneurs? On the relevance (and irrelevance) of the university and the regional context for student start-ups. Small Business Economics, 47(1), 5376. https://doi.org/10.1007/s11187-016-9700-6

Bezerra, É. D., Borges, C., \& Andreassi, T. (2017). Universities, local partnerships and the promotion of youth entrepreneurship. International Review of Education, 63(5), 703-724. https://doi.org/10.1007/s11159-017-9665-y

Bogdanović, M., Vetráková, M., \& Filip, S. (2018). Dark triad characteristics between economics \& business students in Croatia \& Slovakia: what can be expected from the future employees?. Entrepreneurship and Sustainability Issues, 5(4), 967-991. https://doi.org/10.9770/jesi.2018.5.4(19)

BusinessInfo.cz. (2014). Účastníci GEW 2014: Podnikání v Česku stojí v cestě hlavně složité dan. Retrieved from http://www.businessinfo.cz/cs/clanky/ucastnici-gew-2014-podnikani-v-cesku-stoji-v-ceste-hlavne-slozitedane-a-zakony-58675.html

Cañizares, S. M. S., \& García, F. F. J. (2010). Gender differences in entrepreneurial attitudes. Equality, Diversity and Inclusion: An International Journal, 29(8), 766-786. https://doi.org/10.1108/02610151011089519

Chen, C. C., Greene, P. G., \& Crick, A. (1998). Does entrepreneurial self-efficacy distinguish entrepreneurs from managers? Journal of Business Venturing, 13(4), 295-316. https://doi.org/10.1016/S0883-9026(97)00029-3

Dabic, M., Daim, T., Bayraktaroglu, E., Novak, I., \& Basic, M. (2012). Exploring gender differences in attitudes of university students towards entrepreneurship. International Journal of Gender and Entrepreneurship, 4(3), 316-336. https://doi.org/10.1108/17566261211264172

Dawson, C., \& Henley, A. (2015). Gender, Risk, and Venture Creation Intentions. Journal of Small Business Management, 53(2), 501-515. https://doi.org/10.1111/jsbm.12080

Díaz-García, M. C., \& Jiménez-Moreno, J. (2010). Entrepreneurial intention: the role of gender. International Entrepreneurship and Management Journal, 6(3), 261-283. https://doi.org/10.1007/s11365-008-0103-2

Doğan, E. (2015). The effect of enterepreneurship education on entrepreneurial intentions of univesity studnets in Turkey. Ekonometri ve Istatistik E-Dergisi, 23, 79-93.

Entrialgo, M., \& Iglesias, V. (2016). The moderating role of entrepreneurship education on the antecedents of entrepreneurial intention. International Entrepreneurship and Management Journal, 12(4), 1209-1232. https://doi.org/10.1007/s11365-016-0389-4

European Commission. (2012). Rethinking Education: Investing in skills for better socio-economic outcomes. Strasbourg.

Farhangmehr, M., Gonçalves, P., \& Sarmento, M. (2016). Predicting entrepreneurial motivation among university students. Education + Training, 58(7/8), 861-881. https://doi.org/10.1108/ET-01-2016-0019

Fayolle, A., \& Gailly, B. (2015). The Impact of Entrepreneurship Education on Entrepreneurial Attitudes and Intention: Hysteresis and Persistence. Journal of Small Business Management, 53(1), 75-93. https://doi.org/10.1111/jsbm.12065

Fayolle, A., \& Liñán, F. (2014). The future of research on entrepreneurial intentions. Journal of Business Research, 67(5), 663-666. https://doi.org/10.1016/j.jbusres.2013.11.024

Feola, R., Vesci, M., Botti, A., \& Parente, R. (2017). The Determinants of Entrepreneurial Intention of Young Researchers: Combining the Theory of Planned Behavior with the Triple Helix Model. Journal of Small Business Management. https://doi.org/10.1111/jsbm.12361

Filippetti, A., \& Savona, M. (2017). University-industry linkages and academic engagements: individual behaviours and firms' barriers. Introduction to the special section. The Journal of Technology Transfer, 42(4), 719-729. https://doi.org/10.1007/s10961-017-9576-x 
García-Rodríguez, F. J., Gil-Soto, E., Ruiz-Rosa, I., \& Gutiérrez-Taño, D. (2017). Entrepreneurial potential in less innovative regions: the impact of social and cultural environment. European Journal of Management and Business Economics, 26(2), 163-179. https://doi.org/10.1108/EJMBE-07-2017-010

Goel, R. K., Göktepe-Hultén, D., \& Ram, R. (2015). Academics’ entrepreneurship propensities and gender differences. The Journal of Technology Transfer, 40(1), 161-177. https://doi.org/10.1007/s10961-014-9372-9

Goktan, A. B., \& Gupta, V. K. (2015). Sex, gender, and individual entrepreneurial orientation: evidence from four countries. International Entrepreneurship and Management Journal, 11(1), 95-112. https://doi.org/10.1007/s11365013-0278-Z

Hahn, D., Minola, T., Van Gils, A., \& Huybrechts, J. (2017). Entrepreneurial education and learning at universities: exploring multilevel contingencies. Entrepreneurship \& Regional Development, 29(9-10), 945-974. https://doi.org/10.1080/08985626.2017.1376542

Hamida, N., Trabelsi, S., \& Boulila, G. (2017). The impact of active labor market policies on the employment outcomes of youth graduates in the Tunisian governorates. Economics, Management and Sustainability, 2(2), 62-78. https://doi.org/10.14254/jems.2017.2-2.7

Harris, M. L., \& Gibson, S. G. (2008). Examining the entrepreneurial attitudes of US business students. Education + Training, 50(7), 568-581. https://doi.org/10.1108/00400910810909036

Haus, I., Steinmetz, H., Isidor, R., \& Kabst, R. (2013). Gender effects on entrepreneurial intention: a meta-analytical structural equation model. International Journal of Gender and Entrepreneurship, 5(2), 130-156. https://doi.org/10.1108/17566261311328828

Herrington, M., \& Penny, K. (2017). Global Entrepreneurship Monitor Global Report 2016/2017.

Jansen, S., van de Zande, T., Brinkkemper, S., Stam, E., \& Varma, V. (2015). How education, stimulation, and incubation encourage student entrepreneurship: Observations from MIT, IIIT, and Utrecht University. The International Journal of Management Education, 13(2), 170-181. https://doi.org/10.1016/J.IJME.2015.03.001

Joensuu-Salo, S., Varamäki, E., \& Viljamaa, A. (2015). Beyond intentions - what makes a student start a firm? Education + Training, 57(8/9), 853-873. https://doi.org/10.1108/ET-11-2014-0142

Johansen, V. (2013). Entrepreneurship education and start-up activity: a gender perspective. International Journal of Gender and Entrepreneurship, 5(2), 216-231. https://doi.org/10.1108/17566261311328864

Kalitanyi, V., \& Visser, D. J. (2016). Social values as determinants of entrepreneurial intentions among university students in Cape Town - South Africa. Problems and Perspectives in Management, 14(3-1), 185-193. https://doi.org/10.21511/ppm.14(3-1).2016.05

Kirkwood, J., Dwyer, K., \& Gray, B. (2014). Students' reflections on the value of an entrepreneurship education. The International Journal of Management Education, 12(3), 307-316. https://doi.org/10.1016/J.IJME.2014.07.005

Kljucnikov, A., Belas, J., Kozubikova, L., \& Pasekova, P. (2016). The Entreprenurial Perception of SME Business Environment Quality in the Czech Republic. Journal of Competitiveness, 8(1), 66-78. https://doi.org/10.7441/joc.2016.01.05

Kozubíková, L., Belás, J., Bilan, Y., \& Bartoš, P. (2015). Personal characteristics of entrepreneurs in the context of perception and management of business risk in the SME segment. Economics and Sociology, 8(1), 41-54 doi: 10.14254/2071- 789X.2015/8-1/4

Kozubíková, L., Homolka, L., \& Kristalas, D. (2017). The Effect of Business Environment and Entrepreneurs' Gender on Perception of Financial Risk in The Smes Sector. Journal of Competitiveness, 9(1), 36-50. https://doi.org/10.7441/joc.2017.01.03

Kozubíková, L., Vojtovič, S., Rahman, A., Smrčka, L. (2016). The Role of Entrepreneur's Gender, Age and Firms Age in Autonomy. The Case Study from the Czech Republic. Economics and Sociology, 9(2), 168-182. DOI:10.14254/2071-789X.2016/9-2/12

Lafuente, E. M., \& Vaillant, Y. (2013). Age driven influence of role-models on entrepreneurship in a transition economy. Journal of Small Business and Enterprise Development, 20(1), 181-203. https://doi.org/10.1108/14626001311298475

Lazányi, K. (2014a). Entrepreneurs of the future. Serbian Journal of Management, 9(2), 149-158.

Lazányi, K. (2014b). Entrepreneurial skills and competencies of students at Óbuda University. On-line Journal Modelling the New Europe, (10), 17. 
Liñán, F., \& Fayolle, A. (2015). A systematic literature review on entrepreneurial intentions: citation, thematic analyses, and research agenda. International Entrepreneurship and Management Journal, 11(4), 907-933. https://doi.org/10.1007/s11365-015-0356-5

Maes, J., Leroy, H., \& Sels, L. (2014). Gender differences in entrepreneurial intentions: A TPB multi-group analysis at factor and indicator level. European Management Journal, 32(5), $784-794$. https://doi.org/10.1016/j.emj.2014.01.001

Maresch, D., Harms, R., Kailer, N., \& Wimmer-Wurm, B. (2016). The impact of entrepreneurship education on the entrepreneurial intention of students in science and engineering versus business studies university programs. Technological Forecasting and Social Change, 104. https://doi.org/10.1016/j.techfore.2015.11.006

Marinoiu, A.-M., Wahed, L., Zaharia, R., \& Zaharia, R. M. (2017). Foreign students at medical schools in Romania: Empirical evidence about motivations, perceptions and intention after graduation. Transformations in Business \& Economics, 16(2A) (41A), 564.

Marques, C. S. E., Santos, G., Galvão, A., Mascarenhas, C., \& Justino, E. (2018). Entrepreneurship education, gender and family background as antecedents on the entrepreneurial orientation of university students. International Journal of Innovation Science, 10(1), 58-70. https://doi.org/10.1108/IJIS-07-2017-0067

Minniti, M., \& Naudé, W. (2010). What Do We Know About The Patterns and Determinants of Female Entrepreneurship Across Countries? The European Journal of Development Research, 22(3), 277-293. https://doi.org/10.1057/ejdr.2010.17

Mohammad Ahmar Uddin, Shariq Mohammad \& Samir Hammami. (2016). Influence of demographic factors on the entrepreneurial intentions of university students in Oman. Investment Management and Financial Innovations, 13(1-1), 215-220. https://doi.org/10.21511/imfi.13(1-1).2016.08

Mondragón-Vélez, C. (2009). The probability of transition to entrepreneurship revisited: wealth, education and age. Annals of Finance, 5(3-4), 421-441. https://doi.org/10.1007/s10436-008-0117-3

Mueller, S. L., \& Dato-On, M. C. (2008). Gender-role orientation as a determinant of entrepreneurial self-efficacy. Journal of Developmental Entrepreneurship, 13(01), 3-20. https://doi.org/10.1142/S108494670800082X

Mueller, S. L., \& Thomas, A. S. (2001). Culture and entrepreneurial potential: A nine country study of locus of control and innovativeness. Journal of Business Venturing, 16(1), 51-75. https://doi.org/10.1016/S0883-9026(99)00039-7

Nabi, G., Liñán, F., Fayolle, A., Krueger, N., \& Walmsley, A. (2017). The Impact of Entrepreneurship Education in Higher Education: A Systematic Review and Research Agenda. Academy of Management Learning \& Education, 16(2), 277-299. https://doi.org/10.5465/amle.2015.0026

Naushad, M. (2018). A study on the antecedents of entrepreneurial intentions among Saudi students. Entrepreneurship and Sustainability Issues, 5(3), 600-617. https://doi.org/10.9770/jesi.2018.5.3(14)

Nieuwenhuizen, C., Groenewald, D., Davids, J., Janse van Rensburg, L., \& Schachtebeck, C. (2016). Best practice in entrepreneurship education. Problems and Perspectives in Management, 14(3-2), 528-536. https://doi.org/10.21511/ppm.14(3-2).2016.09

Packham, G., Jones, P., Miller, C., Pickernell, D., \& Thomas, B. (2010). Attitudes towards entrepreneurship education: a comparative analysis. Education + Training, 52(8/9), 568-586. https://doi.org/10.1108/00400911011088926

Perez-Quintana, A., Hormiga, E., Martori, J. C., \& Madariaga, R. (2017). The influence of sex and gender-role orientation in the decision to become an entrepreneur. International Journal of Gender and Entrepreneurship, 9(1), 830. https://doi.org/10.1108/IJGE-12-2015-0047

Popov, E., Vlasov, M. \& Horst, H. (2016). Resource Potential of Knowledge Generation. Montenegrin Journal of Economics, 12(3), 101-114.

Pudlo, P., \& Gavurova, B. (2012). Experimental learning in higher education, using simulation games as learning tool. In 12th International Multidisciplinary Scientific GeoConference (pp. 1093-1100). Sofia: SGEM2012 Conference Proceedings. https://doi.org/10.5593/sgem2012/s23.v3009

Pudlo, P., \& Gavurova, B. (2013). Experimental teaching methods in higher education - practical application. In 13th SGEM GeoConference on Ecology, Economics, Education And Legislation (pp. 423-428). Sofia: SGEM2013 Conference Proceedings. https://doi.org/10.5593/SGEM2013/BE5.V2/S22.010

Rauch, A., \& Rijsdijk, S. A. (2013). The Effects of General and Specific Human Capital on Long-Term Growth and Failure of Newly Founded Businesses. Entrepreneurship Theory and Practice, 37(4), 923-941. 
https://doi.org/10.1111/j.1540-6520.2011.00487.x

Sánchez-Escobedo, M. de la C., Díaz-Casero, J. C., Hernández-Mogollón, R., \& Postigo-Jiménez, M. V. (2011). Perceptions and attitudes towards entrepreneurship. An analysis of gender among university students. International Entrepreneurship and Management Journal, 7(4), 443-463. https:/ / doi.org/10.1007/s11365-011-0200-5

Sánchez, J. C. (2011). University training for entrepreneurial competencies: Its impact on intention of venture creation. International Entrepreneurship and Management Journal, 7(2), 239-254. https://doi.org/10.1007/s11365-010-0156-x

Setiawan, J. L. (2014). Examining Entrepreneurial Self-efficacy among Students. Procedia - Social and Behavioral Sciences, 115, 235-242. https://doi.org/10.1016/J.SBSPRO.2014.02.431

Shinnar, R. S., Giacomin, O., \& Janssen, F. (2012). Entrepreneurial Perceptions and Intentions: The Role of Gender and Culture. Entrepreneurship Theory and Practice, 36(3), 465-493. https://doi.org/10.1111/j.15406520.2012.00509.x

Shinnar, R. S., Hsu, D. K., Powell, B. C., \& Zhou, H. (2018). Entrepreneurial intentions and start-ups: Are women or men more likely to enact their intentions? International Small Business Journal: Researching Entrepreneurship, 36(1), 6080. https://doi.org/10.1177/0266242617704277

Shirokova, G., Osiyevskyy, O., \& Bogatyreva, K. (2016). Exploring the intention-behavior link in student entrepreneurship: Moderating effects of individual and environmental characteristics. European Management Journal, 34(4), 386-399. https://doi.org/10.1016/j.emj.2015.12.007

Shirokova, G., Osiyevskyy, O., Morris, M. H., \& Bogatyreva, K. (2017). Expertise, university infrastructure and approaches to new venture creation: assessing students who start businesses. Entrepreneurship \& Regional Development, 29(9-10), 912-944. https://doi.org/10.1080/08985626.2017.1376516

Shirokova, G., Tsukanova, T., \& Morris, M. H. (2018). The Moderating Role of National Culture in the Relationship Between University Entrepreneurship Offerings and Student Start-Up Activity: An Embeddedness Perspective. Journal of Small Business Management, 56(1), 103-130. https://doi.org/10.1111/jsbm.12363

Skačkauskienè, I., Kazlauskienè, E., Katinienè, A. (2017). Modelling Knowledge Synergy Evaluation, Montenegrin Journal of Economics, 12(3),35-49

Social Science Statistics. (n.d.). Z Score Calculator for 2 Poulation Proportions. Retrieved April 28, 2018, from http://www.socscistatistics.com/tests/ztest/Default2.aspx

Stamboulis, Y., \& Barlas, A. (2014). Entrepreneurship education impact on student attitudes. The International Journal of Management Education, 12(3), 365-373. https://doi.org/10.1016/J.IJME.2014.07.001

Trivedi, R. (2016). Does university play significant role in shaping entrepreneurial intention? A cross-country comparative analysis. Journal of Small Business and Enterprise Development, 23(3), 790-811. https://doi.org/10.1108/JSBED-10-2015-0149

Urbano, D., Aparicio, S., Guerrero, M., Noguera, M., \& Torrent-Sellens, J. (2017). Institutional determinants of student employer entrepreneurs at Catalan universities. Technological Forecasting and Social Change, 123, 271-282. https://doi.org/10.1016/J.TECHFORE.2016.06.021

Van Looy, B., Landoni, P., Callaert, J., van Pottelsberghe, B., Sapsalis, E., \& Debackere, K. (2011). Entrepreneurial effectiveness of European universities: An empirical assessment of antecedents and trade-offs. Research Policy, 40(4), 553-564. https://doi.org/10.1016/J.RESPOL.2011.02.001

Walter, S. G., Parboteeah, K. P., \& Walter, A. (2013). University Departments and Self-Employment Intentions of Business Students: A Cross-Level Analysis. Entrepreneurship Theory and Practice, 37(2), 175-200. https://doi.org/10.1111/j.1540-6520.2011.00460.x

Westhead, P., \& Solesvik, M. Z. (2016). Entrepreneurship education and entrepreneurial intention: Do female students benefit? International Small Business Journal, 34(8), 979-1003. https://doi.org/10.1177/0266242615612534

Wilson, F., Kickul, J., \& Marlino, D. (2007). Gender, Entrepreneurial Self-Efficacy, and Entrepreneurial Career Intentions: Implications for Entrepreneurship Education. Entrepreneurship Theory and Practice, 31(3), 387-406. https://doi.org/10.1111/j.1540-6520.2007.00179.x

Zollo, L., Laudano, M. C., Ciappei, C., \& Zampi, V. (2017). Factors affecting universities' ability to foster students' entrepreneurial behaviour. Journal of Management Development, 36(2), 268-285. https://doi.org/10.1108/JMD-062016-0093 